\title{
Is it dextrocardia or dextroversion?
}

\author{
Arunkumar Panneerselvam, ${ }^{1,2}$ Panneerselvam Subbiahnadar ${ }^{3}$ \\ ${ }^{1}$ Cardiology Department, Eugene Clinic, Mettupalayam, TN, India; \\ ${ }^{2}$ Cardiology Department, PSG Institute of Medical Sciences and Research, Coimbatore, TN, India; \\ ${ }^{3}$ Family Medicine Department, S K Selvam hospital, Mettupalayam, TN, India
}

Correspondence to Dr Arunkumar Panneerselvam,drparun1976@gmail.com

\section{DESCRIPTION}

A 69-year-old male, chronic smoker, presented with dyspnoea on exertion of 6 months duration. His clinical examination was unremarkable and his chest x-ray (figure 1) showed cardiac silhouette to be predominantly on the right side of thoracic cavity, mimicking dextrocardia. As it is an apicolardotic posteroanterior view with rotation to right, the cardiac silhouette appears to project further to right side. In addition there is volume loss on the right with compensatory hyperinflation of the left lung causing mediastinal shit. In this x-ray the left hemidiaphragm is at a lower level, so the cardiac situs is levocardia (normally

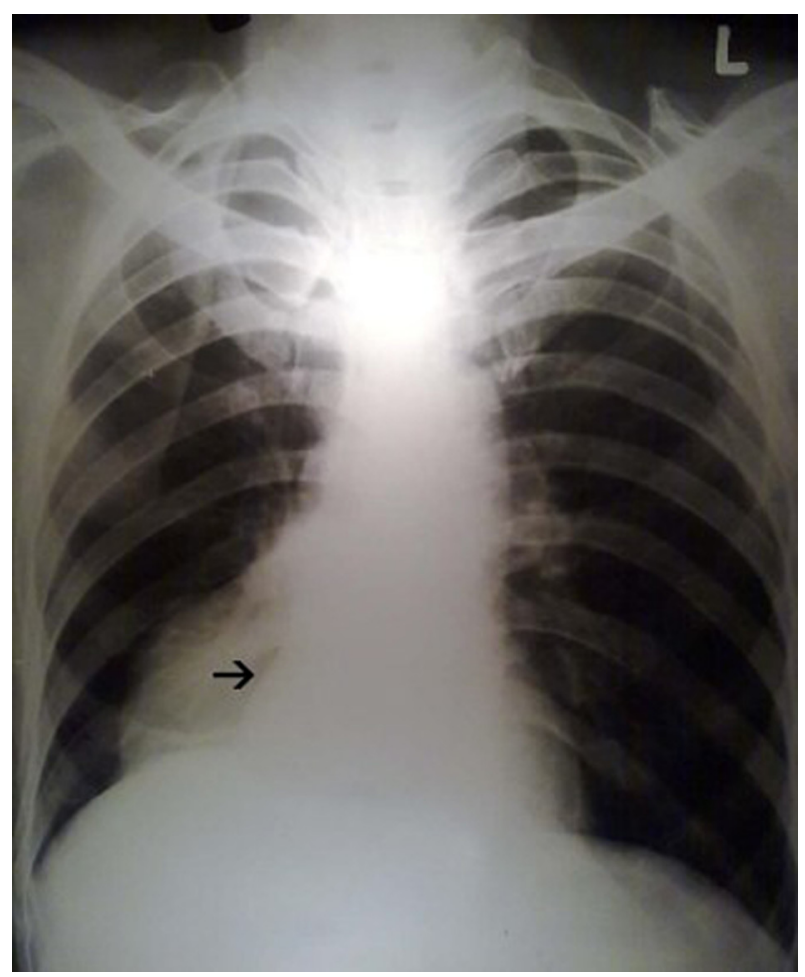

Figure 1 Chest x-ray showing apparent dextrocardia. Note that the left hemidiaphragm is at a lower level, which implies levocardia. The arrow indicates right heart border. The right lower zone lung field opacity is due to segmental collapse of right lower lobe. The convex contour to the visible inferior portion of the right major fissure suggests 'golden S sign' that might indicate underlying mass in right lower lobe. positioned heart with apex pointing to left). On careful analysis the right heart border can be seen within the right lower zone haziness (indicated by arrow). Hence there is shift in position of heart to the right or dextroversion. The abnormal appearance in x-ray is primarily because of segmental collapse of lower lobe of right lung which has manifested as well demarcated right lower zone haziness with distinct right heart border. The visualisation of major fissure (accounting for the contour of the haziness) and downward displacement of the right hilum also points to this diagnosis. The convex contour to the visible inferior portion of the right major fissure suggests a so called 'golden S sign' that might indicate underlying mass in right lower lobe. Dextrocardia is a condition where the heart is located in right hemithorax with its apex pointing to right and in dextroversion the heart is positioned in the chest with the apex still directed to the left. In dextrocardia, the right hemidiaphragm will be at lower level compared with left side, whereas in levocardia the left hemidiaphragm will be at lower level. This is because the cardiac apex pushes the diaphragm downwards. ${ }^{1}$ So identification of cardiac situs should be based on where the cardiac apex is pointing to and level of diaphragm. Dextrocardia could be associated with abdominal situs solitus or inversus (isolated dextrocardia has a strong association with congenital heart disease). Dextroversion could be associated with right pulmonary hypoplasia (Scimitar syndrome) and leftsided chest lesions such as diaphragmatic hernia and cystic adenatoid malfomation in children and acquired space occupying lesions in adult patients. ${ }^{2}$ Features of segmental right lower lobe collapse in x-ray include opacity in right lower lung field with distinct cardiac border, visualisation of major fissure (accounting for the contour of the haziness), downward displacement of the right hilum, invisibility of interlobar pulmonary artery and obscuration of the diaphragm. ${ }^{3}$

\section{Learning points}

- Identifying cardiac situs in x-ray.

- Radiological features of right lower lobe atelectasis.

- Importance of systematic interpretation chest x-ray.

Competing interests None.

Patient consent Obtained. 


\section{BMJ Case Reports}

\section{REFERENCES}

1. Perloff JK. The cardiac malpositions. Am J Cardiol 2011;108:1352-61.
2. Webb WR, Higgins CB. Thoracic Imaging Pulmonary and Cardiovascular Radiology. Philadelphia, PA: Lippincott Williams and Wilkins 2011.

3. Donnelly LF. Diagnostic Imaging: Pediatrics. Salt Lake City: Amirsys 2011.

This pdf has been created automatically from the final edited text and images.

Copyright 2012 BMJ Publishing Group. All rights reserved. For permission to reuse any of this content visit http://group.bmj.com/group/rights-licensing/permissions.

BMJ Case Report Fellows may re-use this article for personal use and teaching without any further permission.

Please cite this article as follows (you will need to access the article online to obtain the date of publication).

Panneerselvam A, Subbiahnadar P. Is it dextrocardia or dextroversion?. BMJ Case Reports 2012;10.1136/bcr.01.2012.5493, Published XXX

Become a Fellow of BMJ Case Reports today and you can:

- Submit as many cases as you like

- Enjoy fast sympathetic peer review and rapid publication of accepted articles

- Access all the published articles

- Re-use any of the published material for personal use and teaching without further permission

For information on Institutional Fellowships contact consortiasales@bmjgroup.com

Visit casereports.bmj.com for more articles like this and to become a Fellow

Keep up to date with all published cases by signing up for an alert (all we need is your email address) http://casereports.bmj.com/cgi/alerts/etoc 